\title{
PEMANFAATAN DANDELION (TARAXACUM OFFICINALE) PADA DIABETES MELLITUS TIPE 2
}

\author{
1| Reyhan Anjani Putri, 2| Ayu Dinda Fatimah \\ Email Korespondensi : fatimahayudinda@gmail.com \\ Program Studi Pendidikan Dokter Umum, Universitas Lampung, Indonesia
}

\begin{abstract}
Diabetes mellitus was one of WHO priority diseases because the number of sufferers is quite high and always increased in every country, especially in Indonesia. Efforts to manage diabetes mellitus from non-pharmacological, pharmacological, to traditional treatments have been carried out. Indonesia is also a country that has a variety of nutritious plants, but only a few plants have been used as traditional medicine. The purpose of this study was to find out how the utilization would be done using dandelion or Taraxacum officinale for type 2 diabetes mellitus so that the results would be useful to increase knowledge for health providers and the people of Indonesia in utilizing the natural resources in Indonesia. This type of research was a literature review and the method used in this study literature was collecting 21 literature from books and 30 case report and research article journals. Conclusion: One of the medicinal plants found in Indonesia was dandelion plant (Taraxacum officinale) which was known to have antihyperglycemic or antidiabetic effects, but its use in Indonesia was quite rare. Antidiabetic mechanisms of this plant are reabsorption of the glucose in the kidneys, reducing the activity of the enzyme alpha-amylase and alpha-glucosidase, reducing glucose levels in the blood, and inhibiting the flow of potassium channels.
\end{abstract}

\begin{abstract}
Abstrak
Diabetes mellitus merupakan penyakit yang menjadi salah satu pusat perhatian WHO karena jumlah penderitanya yang cukup tinggi dan selalu mengalami peningkatan pada setiap negara, khususnya di Indonesia. Upaya penatalaksanaan diabetes mellitus dari tatalaksana nonfarmakologi, farmakologi, hingga pengobatan tradisional sudah banyak dilakukan. Indonesia juga merupakan negara yang memiliki beragam tanaman berkhasiat, tetapi hanya sedikit tanaman yang sudah digunakan sebagai tanaman sebagai obat tradisional. Tujuan penelitian ini adalah untuk mengetahui bagaimana pemanfaatan yang dapat dilakukan menggunakan dandelion atau taraxacum officinale terhadap kondisi diabetes mellitus tipe 2. Sehingga hasilnya dapat bermanfaat untuk menambah pengetahuan bagi penatalaksana kesehatan dan masyarakat Indonesia dalam memanfaatkan kekayaan sumber daya alam di Indonesia dengan baik. Jenis penelitian ini adalah tinjauan literatur dengan metode yang digunakan adalah mengumpulkan hasil baca dari sumber berupa 21 buku dan 30 jurnal laporan kasus dan jurnal artikel penelitian. Kesimpulan: Salah satu tanaman obat yang terdapat di Indonesia adalah tanaman dandelion (Taraxacum officinale) yang diketahui memiliki efek antihiperglikemia atau antidiabetes, tetapi penggunaannya di Indonesia masih jarang. Mekanisme antidiabetes yang terjadi adalah mereabsorpsi glukosa di ginjal, mengurangi aktivitas enzim alfa-amylase dan alfa-glukosidase, mengurangi kadar glukosa dalam darah, serta menghambat aliran saluran kalium.
\end{abstract}

\section{Kata Kunci: Diabetes Mellitus; Antihiperglikemia; Antidiabetes; Dandelion (Taraxacum officinale)}

\section{PENDAHULUAN}

Penyakit diabetes mellitus merupakan penyakit kronis yang berhubungan dengan metabolisme tubuh yang ditandai dengan hiperglikemia atau kadar glukosa darah yang tinggi akibat kecacatan pada saat sekresi hormon insulin, kerja hormon insulin, ataupun keduanya(1). Hormon insulin terdiri dari protein yang disintesis di 
sel beta pankreas. Hormon ini akan dikeluarkan oleh sel beta pankreas sebagai respon terhadap rangsangan berupa menempelnya glukosa pada reseptor GLUT2(2). Diabetes mellitus merupakan salah satu dari empat penyakit tidak menular yang menjadi perhatian utama yang diidentifikasi oleh World Health Organization (WHO) bersama dengan serangan jantung dan stroke, kanker, serta penyakit pernapasan kronis(3). Hal ini karena diabetes mellitus merupakan penyakit kronis dengan jumlah kasus dan prevalensi yang terus mengalami peningkatan selama beberapa dekade terakhir(4).

Jumlah penderita diabetes mellitus cukup tinggi dan selalu mengalami peningkatan pada setiap negara di dunia secara umum. Kondisi ini beriringan dengan prevalensi obesitas dan prevalensi gaya hidup tidak sehat yang juga mengalami peningkatan(5). Pada tahun 2000 terdapat sebanyak 171 juta penderita diabetes mellitus di dunia dengan persentase 2,8\% dari jumlah total penduduk di dunia. Saat itu diperkirakan pada tahun 2030 terjadi peningkatan jumlah penderita diabetes hingga mencapai 366 juta jiwa atau setara dengan 4,4\% dari jumlah total populasi dunia(6).

Pada tahun 2011, jumlah penderita diabetes mellitus di dunia sudah mencapai 366 juta jiwa dengan jumlah penderita terbanyak berasal dari negara dengan pendapatan rendah sampai sedang(7). Selanjutnya, pada tahun 2017 terdapat 451 juta jiwa di dunia menderita diabetes mellitus yang berarti angka penderita diabetes mellitus selalu mengalami peningkatan sehingga angka perkiraan jumlah penderita diabetes mellitus juga terus mengalami peningkatan yaitu sebanyak 693 juta jiwa mengalami diabetes mellitus pada tahun 2045. Selain itu juga diperkirakan 49,7\% dari total jumlah penderita diabetes mellitus tidak mengetahui penyakit yang dideritanya atau belum terdiagnosis(8).

Diabetes mellitus merupakan masalah kesehatan dunia yang paling sering terjadi pada negara berkembang(9). Diabetes mellitus paling banyak terjadi di benua Asia. Hal ini terjadi karena terdapat negara-negara Asia yang juga menjadi negara dengan penduduk terbanyak di dunia dan sebagian besar negara di benua Asia sedang mengalami perkembangan ekonomi sehingga terjadi pula perubahan pola makan yang signifikan hingga dapat menyebabkan resistensi insulin karena peningkatan konsumsi nasi putih(10).

Sebagai salah satu negara di benua Asia, Indonesia merupakan negara dengan angka penderita diabetes mellitus yang selalu mengalami peningkatan jumlah dari tahun ke tahun(11). Pada tahun 1980, proporsi diabetes mellitus pada penduduk usia 15 tahun ke atas sebesar 1,5-2,3\% dengan prevalensi di daerah pedesaan lebih rendah dibanding daerah perkotaan(12). Secara epidemiologi, diperkirakan pada tahun 2030 prevalensi diabetes mellitus di Indonesia mencapai 21,3 juta orang yang 
terdiri dari $14,7 \%$ penduduk perkotaan dan 5,8\% penduduk pedesaan di Indonesia(13).

Pada penyakit diabetes mellitus tipe 2 terdapat dua cara penatalaksanaan, yaitu tanpa obat dan dengan obat. Penatalaksanaan tanpa obat atau non-farmakologi maksudnya adalah dengan pengaturan diet atau pola makan dan olahraga atau aktivitas fisik lainnya(14). Tujuan penatalaksanaan terhadap penderita diabetes mellitus tipe 2 adalah untuk menghindari dekompensasi akut, mencegah atau memperlambat munculnya komplikasi penyakit diabetes mellitus, menurunkan angka kematian, dan mempertahankan kualitas hidup yang baik (15).

Pengaturan pola makan bertujuan untuk mencapai HbA1c 7\%, tekanan darah kurang dari sama dengan 140/80 mmHg, kolesterol LDL $100 \mathrm{mg} / \mathrm{dL}$, trigliserida 150 mg/dL, kolsterol HDL 40 mg/dL untuk laki-laki dan kolesterol HDL 50 mg/dL untuk perempuan. Pengaturan pola makan juga bertujuan untuk mencapai berat badan ideal untuk menurunkan kemungkinan terjadinya komplikasi(16). Jumlah makanan yang dikonsumsi oleh penderita penyakit diabetes harus memperhatikan porsi dan kandungannya. Kandungan pada makanan yang dikonsumsi sebaiknya terdri atas karbohidrat kompleks, rendah lemak jenuh, tinggi protein selain protein hewani, serta rendah sodium atau garam. Makanan yang dikonsumsi juga sebaiknya tinggi vitamin dan mineral(17). Sudah terbukti bahwa daging merah, makanan manis, dan makanan yang digoreng dapat meningkatkan risiko terjadi resistensi insulin sehingga menyebabkan diabetes mellitus, sedangkan konsumsi buah dan sayuran atau tanaman lain dapat menurunkan risiko diabetes mellitus karena mengandung tinggi serat dan antioksidan(18).

Aktivitas fisik harus dianjurkan untuk semua penderita diabetes mellitus sebagai usaha untuk menjaga kadar glukosa darah dan mencegah komplikasi. Rekomendasi aktivitas fisik setiap orang bervariasi berdasarkan jenis diabetes, usia, aktivitas yang dilakukan, dan komplikasi kesehatan terkait diabetes yang sudah dialami(19). Rekomendasi secara umum bagi penderita diabetes mellitus tipe 2 adalah latihan harian yang tidak boleh memiliki waktu libur lebih dari dua hari untuk memaksimalkan kerja insulin. Latihan harian ini sebaiknya merupakan latihan aerobik yang dilakukan setidaknya 150 menit dalam satu minggu. Pada anggota keluarga atau orang yang beresiko menderita diabetes mellitus juga dianjurkan melakukan latihan fisik dengan hasil yang diharapkan adalah penurunan berat badan 5-7\%(20). Penurunan berat badan ini bertujuan positif yaitu untuk mencegah terjadinya diabetes mellitus tipe 2(21).

Penatalaksanaan farmakologi menggunakan obat yang utama adalah metformin(22). Metformin merupakan salah satu obat dari 4 golongan obat yang paling banyak digunakan untuk penderita diabetes mellitus tipe 2. Golongan secretagenous terdiri atas sulfonylurea dan meglitinides yang bekerja dengan cara 
meningkatkan ketersediaan insulin, selanjutnya golongan biguanid contohnya metformin yang menekan pelepasan glukosa hati berlebihan, selanjutnya golongan thiazolidinediones yang bekerja dengan cara meningkatkan sensitivitas insulin, serta inhibitor $\alpha$-glukosidase yang bekerja dengan cara menunda penyerapan glukosa di sistem gastrointestinal(23).

Tatalaksana farmakologi lini pertama adalah metformin dengan dosis awal adalah $500 \mathrm{mg}$ dan dosis maksimal adalah $2000 \mathrm{mg}$ per hari(24). Metformin bekerja dengan cara menghambat produksi glukosa oleh hepar melalui penurunan glukoneogenesis, mengurangi penyerapan glukosa di usus, dan meningkatkan pemanfaatan glukosa tanpa melibatkan insulin endogen sehingga menurunkan kemungkinan terjadinya hipoglikemia(25). Tetapi dalam penggunaan metformin harus memperhatikan fungsi ginjal, karena gangguan ginjal merupakan kontraindikasi dari penggunaan metformin. Apabila terdapat gangguan ginjal, maka pengobatan dapat menggunakan sulfonylurea(26).

Diabetes mellitus terutama disebabkan oleh stres oksidatif yang terdapat pada sel beta pankreas sehingga mengganggu proses-proses yang terjadi pada sel beta pankreas termasuk sekresi insulin(27). Penderita diabetes mellitus dianjurkan untuk lebih banyak mengonsumsi sayuran atau tanaman lain yang diketahui dapat menurunkan risiko diabetes mellitus karena mengandung antioksidan alami yang memiliki kemampuan untuk mempertahankan kinerja sel beta dan menurunkan kadar glukosa dalam darah(18). Selain itu juga tanaman obat lebih terjangkau oleh masyarakat(27).

Indonesia merupakan negara yang kaya akan tumbuh-tanaman dengan spesies yang sangat beragam. Beberapa tanaman di Indonesia sering digunakan sebagai obatobatan untuk terapi atau penyembuhan dan juga untuk profilaksis atau pencegahan suatu penyakit(28). Tanaman di Indonesia masih sering digunakan sebagai pengganti obat-obatan karena khasiatnya yang masih dapat dipercaya. Pengobatan berbahan dasar tanaman ini bekerja terutama karena mengandung beberapa bahan kimia yang berinteraksi dengan tubuh manusia atau sistem kekebalan untuk memerangi penyakit. Oleh karena itu, seiring berjalannya waktu, para ilmuwan mulai mempelajari komposisi kimia dari obat-obatan herbal tradisional(29).

Tanaman obat merupakan pengobatan cara tradisional yang banyak digunakan di Indonesia, tetapi keamanan dan efektivitas masih kurang didukung oleh penelitian yang komprehensif(30). Tanaman yang termasuk tanaman obat di Indonesia mencakup 15 jenis tanaman, yaitu jahe, laos atau lengkuas, kencur, kunyit, lempuyang, temulawak, temuireng, temukunci, dlingo atau dringo, kapulaga, mengkudu atau pace, mahkota dewa, kejibeling, sambiloto, dan lidah buaya(31). Tetapi sebenarnya tanaman obat memiliki ribuan jenis spesies dan diketahui bahwa $90 \%$ dari tanaman obat yang terdapat di wilayah Asia. Dari jumlah tersebut hanya 
sekitar 1200 jenis tanaman sudah diketahui memiliki khasiat herbal dan dimanfaatkan sebagai tanaman obat(32).

Dandelion merupakan salah satu tanaman yang dimanfaatkan sebagai tanaman obat tradisional, terutama di benua Asia, Eropa, dan Amerika bagian utara terutama berkaitan dengan penyembuhan sistem gastrointestinal(33). Banyak penelitian preklinik mengungkapkan bahwa dandelion memiliki beragam sifat, yaitu modulator inflamasi, diuretic, stimulant pada sistem gastrointestinal, stimulan insulin, anti nyeri, prebiotik, imunomodulator, antiangiogenik, dan antineoplastik. Penelitian juga telah mengungkapkan bahwa dandelion diketahui mengandung berbagai komponen bioaktif yang berpotensi memiliki sifat antidiabetik(34).

Penelitian-penelitian sebelumnya sangat banyak membahas tanaman-tanaman obat, khususnya 15 jenis tanaman, yaitu jahe, laos atau lengkuas, kencur, kunyit, lempuyang, temulawak, temuireng, temukunci, dlingo atau dringo, kapulaga, mengkudu atau pace, mahkota dewa, kejibeling, sambiloto, dan lidah buaya. Tetapi di Indonesia masih sedikit yang membahas tanaman obat lain, khususnya dandelion atau Taraxacum officinale.

Penelitian ini bertujuan untuk mengetahui apakah dandelion atau Taraxacum officinale memiliki manfaat terhadap diabetes mellitus tipe 2. Sehingga hasilnya dapat bermanfaat untuk menambah pengetahuan bagi penatalaksana kesehatan dan masyarakat Indonesia dalam memanfaatkan kekayaan sumber daya alam di Indonesia dengan baik.

\section{METODOLOGI PENELITIAN}

Penelitian ini berjenis tinjauan literatur atau literature review yang disusun menggunakan data sekunder berupa sumber yang diperoleh berdasarkan daftar pustaka yang tertera. Metode yang digunakan dalam pembuatan penelitian ini adalah mengumpulkan hasil baca dari sumber berupa buku, jurnal, laporan kasus, dan artikel penelitian. Sumber yang menjadi landasan teori terdiri dari 19 buku serta 30 jurnal berjenis laporan kasus dan artikel penelitian.

\section{HASIL DAN PEMBAHASAN}

\section{Diabetes Mellitus}

Diabetes mellitus adalah penyakit metabolisme yang ditandai dengan hiperglikemia kronis karena kecacatan pada sekresi insulin, kerja insulin, ataupun keduanya. Keadaan hiperglikemia ini menyebabkan gangguan pada metabolisme karbohidrat, lemak, dan protein(35). Gejala yang ditimbulkan oleh penyakit ini adalah polyuria, polydipsia, dan penurunan berat badan. Gejala tambahan yang 
mungkin terjadi juga adalah polifagia dan penglihatan kabur(36). Selain itu juga pada diabetes mellitus konsentrasi glukosa plasma vena lebih dari sama dengan 200 $\mathrm{mg} / \mathrm{dL}$ atau 11,1 mmol/L, glukosa puasa pada plasma kapiler atau vena lebih dari sama dengan $126 \mathrm{mg} / \mathrm{dL}$ atau 7,0 mmol/L, atau hemoglobin A1c lebih dari sama dengan 6,5\%. Pemeriksaan diabetes mellitus tipe 2 ini sebaiknya dilakukan berdasarkan kriteria yaitu berat badan berlebih ditambah dengan adanya riwayat keluarga terdapat penderita diabetes mellitus tipe 2; ras Asia, Amerika, atau Africa; atau terdapat tanda-tanda adanya resistensi insulin pada tubuh, contohnya hipertensi, dyslipidemia, acanthosis nigricans, atau sindrom polikistik ovarium(37).

Diabetes mellitus diklasifikasikan oleh American Diabetes Association menjadi 4 kategori. Pertama adalah diabetes mellitus tipe 1 yang terjadi karena kerusakan sel beta pankreas karena autoimun yang biasanya mengarah ke defisiensi insulin absolut. Kedua adalah diabetes mellitus tipe 2 yang terjadi karena kecacatan pada saat sekresi insulin oleh sel beta pankreas atau aktivitas insulin karena resistensi insulin. Ketiga adalah diabetes mellitus gestasional yang merupakan kategori diabetes yang didiagnosis pada detik atau ketiga trimester kehamilan dimana kondisi ini tidak jelas diabetes sebelum kehamilan. Keempat adalah jenis diabetes spesifik karena penyebab lain, contohnya sindrom diabetes monogenik, penyakit pada pankreas eksokrin, atau diabetes yang diinduksi oleh obat atau bahan kimia(38). Diabetes mellitus tipe 2 merupakan kategori diabetes mellitus yang paling banyak diderita di dunia(39). Secara global, dari seluruh total penderita, kategori diabetes mellitus tipe 2 memiliki persentase 90\% sampai 95\% sementara diabetes mellitus tipe 1 menempati posisi kedua dengan persentase $1 \%$ sampai $4 \%$ dari populasi dunia(40).

Diabetes mellitus merupakan penyakit kronis yang dapat menimbulkan berbagai komplikasi apabila tidak ditangani dengan baik(35). Komplikasi diabetes mellitus terdiri komplikasi akut dan kronis. Komplikasi akut terdiri dari hipoglikemia, krisis hiperglikemia, dan ketoasidosis diabetikum. Sementara komplikasi kronis yang dapat terjadi adalah retinopati diabetikum, nefropati diabetikum, neuropati diabetikum, dan lain-lain(41).

Diabetes mellitus tipe 2 terjadi karena sel beta pankreas mengalami penurunan fungsi secara terus-menerus sehingga mengganggu kualitas produksi hormon insulin. Insulin yang disekresikan oleh sel beta pankreas akan dilepaskan sebagai respons terhadap stimulasi glukosa, asam lemak, atau asam amino(42). Keadaan utama yang terjadi pada diabetes mellitus tipe 2 adalah gangguan sekresi insulin atau resistensi insulin. Gangguan sekresi insulin disebabkan oleh penurunan respon terutama terhadap glukosa. Gangguan ini cenderung bersifat progresif dan mempengaruhi pankreas dengan cara menurunkan kualitas sel beta pankreas. Apabila terjadi secara terus-menerus, penurunan fungsi sel ini dapat menyebabkan peningkatan glukosa 
darah secara permanen(43). Dalam kondiri resistensi insulin, sel beta pankreas akan berusaha meningkatkan pengeluaran insulin untuk mempertahankan toleransi glukosa normal. Namun, jika sel beta pankreas tidak mampu lagi mengeluarkan insulin dalam jumlah yang dibutuhkan, maka akan terjadi peningkatan glukosa dalam plasma darah(41).

\section{Tanaman Dandelion (Taraxacum officinale)}

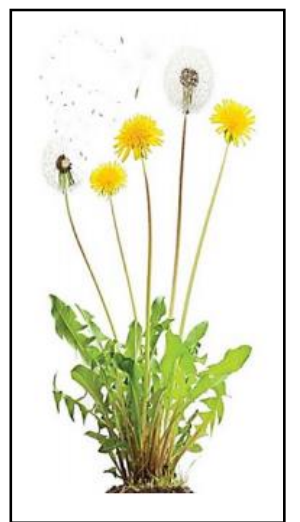

Gambar 1: Tanaman Dandelion (Taraxacum officinale)

Dandelion merupakan nama yang umum dikenal sebagai Taraxacum officinale. Dandelion berarti gigi singa. Nama ini merujuk pada bentuk daun yang bergerigi atau akar tunggang putih yang kuat. Sementara nama Taraxacum merupakan serapan dari bahasa Arab dandelion yang berarti ceri liar. Officinale merupakan serapan dari bahasa Yunani yang berarti menyembuhkan(44). Nama lain dari tanaman ini yang paling umum di Indonesia adalah tanaman jombang atau taraksakum(45). Taksonomi tanaman dandelion atau jombang adalah sebagai berikut (46).

Tabel 1. Taksonomi Taraxacum officinale

\begin{tabular}{ll}
\hline \multicolumn{2}{l}{ Taksonomi Taraxacum Officinale } \\
\hline Nama binomial & Taraxacum officinale \\
\hline Kingdom & Plantae \\
\hline Divisi & Magnoliophyta \\
\hline Kelas & Magnoliopsida \\
\hline Ordo & Asterales \\
\hline Famili & Asteraceae \\
\hline Genus & Taraxacum \\
\hline Spesies & Officinale \\
\hline
\end{tabular}

Dandelion mengandung senyawa-senyawa kimia yang bermanfaat bagi tubuh, salah satunya adalah polifenol yang bekerja sebagai antioksidan yang mampu mencegah diabetes mellitus(47). Senyawa kimia lainnya adalah lakton yang diketahui 
memiliki sifat antiinflamasi dan antikanker, fenilpropanoid yang memiliki fungsi imunitas, serta inulin yang memiliki efek analgesic atau antinyeri. Selain itu secara umum, pada akar dan daun tanaman dandelion diketahui mampu menurunkan kadar gukosa darah pada penderita diabetes mellitus(33).

\section{Pemanfaatan Dandelion (Taraxacum Officinale) pada sebagai Antidiabetes}

Dandelion (Taraxacum officinale) merupakan tanaman yang mengandung senyawa polifenol yang berperan sebagai antioksidan yang dapat melindungi sel $\beta$ dari spesies oksigen reaktif (ROS) sehingga diharapkan mampu mencegah diabetes yang disebabkan oleh ROS(48). Komponen polifenol yang terdapat pada tanaman dandelion menyebabkan aktivasi CAMP yang meningkatkan eksositosis dalam sel $\beta$, penghambatan proses degradasi insulin, pencegahan stres oksidatif, regenerasi sel $\beta$, perbaikan hipertrofi seluler, dan proliferasi sel-sel di pulau Langerhans(47).

Selain itu, polifenol juga diketahui dapat menimbulkan efek antihiperglikemia. Mekanisme yang terjadi adalah dengan mengikat transporter glukosa dan secara kompetitif akan menghambat enzim pencernaan, yaitu enzim alfa-amilase dan alfaglukosidase lebih signifikan daripada acarbosa yang umum digunakan sebagai obat antidiabetes(48). Secara mendalam, diketahui bahwa pada bagian akar dari tanaman dandelion mengandung inulin atau fructooligosaccharides (FOS). FOS adalah karbohidrat kompleks yang baik dalam menjaga kadar glukosa normal dalam darah serta mampu menstimulasi sistem kekebalan tubuh(34).

Secara umum, mekanisme antidiabetes yang berasal dari senyawa-senyawa tanaman dandelion adalah dengan cara menghambat reabsorpsi glukosa di ginjal, mengurangi aktivitas enzim yang terlibat dalam metabolisme karbohidrat seperti enzim alfa-amylase dan alfa-glukosidase, mengurangi kadar glukosa dalam darah sehingga mencegah glikolisis di hati, serta menghambat aliran saluran kalium(47).

Salah satu cara memanfaatkan dandelion adalah disarankan dalam bentuk akar atau daun kering dengan dosis 4 gram sampai 10 gram setiap hari dalam dosis terbagi. Secara tradisional umumnya akar atau daun segar dapat dikonsumsi hingga 50 gram perhari. Tetapi di Amerika Serikat umumnya memanfaatkan dandelion dalam bentuk larutan akar atau daunnya dengan dosis $3 \mathrm{~mL}$ sampai $5 \mathrm{~mL}$ sebanyak tiga kali sehari(33). Pemanfaatan dandelion yang umum di Indonesia dalah dengan cara meminumnya, yaitu sebanyak 15 sampai 30 gram tanaman segar direbus atau ditumbuk, lalu diperas dan dikonsumsi. Selain itu dapat juga menggunakan 10 sampai 30 gram akar tanaman yang direbus(45).

Dalam penggunaan dandelion ini perlu diperhatikan apakah seseorang memiliki alergi terhadap dandelion atau tanaman family Asteraceae lainnya. Selain itu karena rasanya pahit, maka mengonsumsi dandelion ini dapat memperburuk kondisi 
penderita peradangan atau obstruksi gastrointestinal akut dan refluks esophagus(49). Selanjutnya pada dandelion belum diketahui terdapat interaksi dengan obat lain, tetapi pada penggunaannya bersama dengan ciprofloxacin, kandungan mineral yang tinggi pada dandelion dapat menurunkan efektivitas dan daya kerja ciprofloxacin(50).

\section{KESIMPULAN}

Diabetes mellitus merupakan penyakit metabolik kronis yang ditandai dengan peningkatan kadar glukosa darah. Jumlah penderita diabetes mellitus di Indonesia cukup banyak dan selalu mengalami peningkatan dari tahun ke tahun, dengan persentase paling banyak adalah pada kategori diabetes mellitus tipe 2. Salah satu pengobatan tradisional di Indonesia adalah dengan menggunakan tanaman obat. Meskipun jarang di bahas pada beberapa penelitian, dandelion (Taraxacum officinale) atau tanaman jombang juga dapat dimanfaatkan sebagai tanaman obat salah satunya sebagai antidiabetes. Mekanisme antidiabetes yang terjadi adalah mereabsorpsi glukosa di ginjal, mengurangi aktivitas enzim alfa-amylase dan alfa-glukosidase, mengurangi kadar glukosa dalam darah, serta menghambat aliran saluran kalium. Berdasarkan hasil tinjauan literature diperoleh kesimpulan bahwa dandelion atau Taraxacum officinale memiliki manfaat terhadap diabetes mellitus tipe 2 .

\section{SARAN}

Saran dari penulis untuk penelitian selanjutnya adalah agar melakukan penelitian lebih mendalam seperti penelitian intervensi atau observasional terhadap hewan coba ataupun terhadap manusia atau penelitian berupa laporan kasus agar hasil penelitian merupakan hasil yang didapatkan secara langsung atau melalui sumber primer.

\section{DAFTAR PUSTAKA}

1. Ministry of Public Health and Sanitation. National Clinical Guidelines For Management of Diabetes Mellitus. Nairobi; 2010.

2. Joshi SR, Parikh RM, Das AK. Insulin--history, biochemistry, physiology and pharmacology. The Journal of the Association of Physicians of India. 2007;55 Suppl(December 1921):19-25.

3. International Diabetes Federation. Global Diabetes Plan 2011-. New York; 2011.

4. WHO. Global Report on Diabetes. Geneva; 2016.

5. Forouhi NG, Wareham NJ. Epidemiology of diabetes. Medicine (United Kingdom). 2014;47(1):22-7. 
6. Wild S, Roglic G, Green A, Sicree R KH. Global Prevalence of Diabetes: Estimates for the year 2000 and projections for 2030. Diabetes Care. 2004;27(5):1047-53.

7. Whiting DR, Guariguata L, Weil C, Shaw J. IDF Diabetes Atlas: Global estimates of the prevalence of diabetes for 2011 and 2030. Diabetes Research and Clinical Practice. 2011;94(3):311-21.

8. Cho NH, Shaw JE, Karuranga S, Huang Y, da Rocha Fernandes JD, Ohlrogge AW, et al. IDF Diabetes Atlas: Global estimates of diabetes prevalence for 2017 and projections for 2045. Diabetes Research and Clinical Practice. 2018;138:271-81.

9. Buowari OY. Diabetes Mellitus in Developing Countries and Case Series. Diabetes Mellitus - Insights and Perspectives. 2013;

10. Rhee E. Review Article Diabetes in Asians. Endocrinol ogy and Metabolism. 2015;30:263-9.

11. Soewondo P, Ferrario A, Tahapary DL. Challenges in diabetes management in Indonesia: A literature review. Globalization and Health. 2013;9(1):1-17.

12. Kementerian Kesehatan RI. Info Datin: Situasi dan Analisis Diabetes. Kementerian Kesehatan RI RI. 2014.

13. Kementerian Kesehatan RI. Tahun 2030 Prevalensi Diabetes Melitus Di Indonesia Mencapai 21,3 Juta Orang. Kementrian Kesehatan RI. 2009.

14. Kementerian Kesehatan RI. Pharmaceutical Care Untuk Penyakit Diabetes Mellitus. Jakarta: Kementerian Kesehatan RI; 2005.

15. Simó R, Hernández C. Treatment of diabetes mellitus: General goals, and clinical practice management. Revista Espanola de Cardiologia. 2002;55(8):845-60.

16. Paswan SKr, Verma P, Raj A, Azmi L, Shrivastava S, Rao Ch V. The Role of Nutrition Therapy in the Management of Diabetes Mellitus. Nutrition in Clinical Care. 2016;3(1):1-6.

17. Evert AB, Boucher JL, Cypress M, Dunbar SA, Franz MJ, Mayer-Davis EJ, et al. Nutrition therapy recommendations for the management of adults with diabetes. Diabetes Care. 2014;37(1):120-43.

18. Sami W, Butt TA, Shafique N, Hamid MRA. Effect of diet on type 2 diabetes mellitus: A review. 2017;11(2).

19. Colberg SR, Sigal RJ, Fernhall B, Regensteiner JG, Blissmer BJ, Rubin RR, et al. Exercise and type 2 diabetes: The American College of Sports Medicine and the American Diabetes Association: Joint position statement. Diabetes Care. 2010;33(12). 
20. Colberg SR, Sigal RJ, Yardley JE, Riddell MC, Dunstan DW, Dempsey PC, et al. Physical activity/exercise and diabetes: A position statement of the American Diabetes Association. Diabetes Care. 2016;39(11):2065-79.

21. Gautier J, Duclos M, Oppert JM, Verges B, Coliche V, Guezennecg Y, et al. Physical activity and type 2 diabetes. Recommandations of the SFD (Francophone Diabetes Society) diabetes and physical activity working group. Diabetes \& Metabolism Journal. 2015;39(October):205-16.

22. American Diabetes Associaion. Pharmacologic approaches to glycemie treatment: Standards of medical care in diabetes-2019. Diabetes Care. 2019;42(1):90-102.

23. Wall RT. Endocrine disease. In: Stoelting's Anesthesia and Co-existing Disease. Philadelphia: Elsevier; 2018.

24. Skugor M. Diabetes Mellitus. In: Ryan's Retina. Philadelphia: Elsevier Inc.; 2019. p. 1055-60.

25. Gong L, Goswami S, Giacomini KM, Altman RB, Klein TE. Metformin pathways: pharmacokinetics and pharmacodynamics. Pharmacogenetics and Genomics. 2012;22(11):820-7.

26. Bajaj S. RSSDI clinical practice recommendations for the management of type 2 diabetes mellitus 2017. Vol. 38, International Journal of Diabetes in Developing Countries. 2018. 1-115 p.

27. Kooti W, Farokhipour M, Asadzadeh Z, Ashtary-Larky D, Asadi-Samani M. The role of medicinal plants in the treatment of diabetes: a systematic review. Electronic physician. 2016;8(1):1832-42.

28. Mitra R, Mitchell, Gray C, Orbell J, Coulepis T, Muralitharan MS. Medicinal Plants of Indonesia. APBN. 2007;11(11):726-43.

29. Departemen Perdagangan RI. Indonesian Herbal The Traditional Therapy. Jakarta: Ministry Trade Research \& Development Agency; 2009.

30. Indonesian Traditional Medicine Nationat Strategy and Scope Cooperation. Traditional Medicine in Republic of Indonesian. Jakarta: Indonesian Traditional Medicine Nationat Strategy and Scope Cooperation; 2007.

31. Kementerian Pertanian RI. Statistik Produksi Hortikultura Tahun 2014. Jakarta: Kementerian Pertanian RI; 2014.

32. Kementerian Perdagangan RI. Info Komoditi Tanaman Obat. Jakarta: Kementerian Perdagangan RI; 2017.

33. Yarnell E, Abascal K. Dandelion (Taraxacum officinale and T mongolicum). Integrative Medicine. 2009;8(2):35. 
34. Fatima T, Bashir O, Naseer B, Hussain SZ. Dandelion: Phytochemistry and clinical potential. Journal of Medicinal Plants Studies. 2018;6(2):198-202.

35. WHO. Definition, Diagnosis and Classification pf Diabetes Mellitus and its Complications. Geneva: WHO; 1999.

36. American Diabetes Association. Diagnosis and classification of autoimmune diabetes mellitus. Diabetes Care. 2010;33(1).

37. Reinehr T. Type 2 diabetes mellitus in children and adolescents. World Journal of Diabetes. 2013;4(6).

38. American Diabetes Association. Standards of Medical Care in Diabetes-2018. Vol. 41, Diabetes care. USA: American Diabetes Association; 2018.

39. Olokoba AB, Obateru OA, Olokoba LB. Type 2 Diabetes Mellitus: A Review of Current Trends. Oman Medical Journal. 2012;2(4).

40. McCall, Saunders, Gosmanov, Gosmanova. Diabetes mellitus in adults. In: Conn's Current Therapy. Philadelphia: Elsevier; 2019.

41. Baynest HW. Classification, Pathophysiology, Diagnosis and Management of Diabetes Mellitus. Journal of Diabetes \& Metabolism. 2015;6(5).

42. Kahn SE, Cooper ME, Del Prato S. Pathophysiology and treatment of type 2 diabetes: Perspectives on the past, present, and future. The Lancet. 2014;383(9922):1068-83.

43. Kaku K. Pathophysiology of Type 2 Diabetes and Its Treatment Policy. JMAJ. 2010;53(1):41-6.

44. Stewart-Wade SM, Neumann S, Collins LL, Boland GJ. The biology of Canadian weeds. 117. Taraxacum officinale G. H. Weber ex Wiggers. Canadian Journal of Plant Science. 2002;

45. Badrunasar A, Santoso HB. Tumbuhan Liar Berkhasiat Obat. Bogor: Forda Press; 2017.

46. Dalimarta S. Ensiklopedi tanaman obat indonesia. Jakarta: Dinamika Media; 2008.

47. Wirngo FE, Lambert MN, Jeppesen PB. The physiological effects of dandelion (Taraxacum officinale) in type 2 diabetes. Review of Diabetic Studies. 2016;13(2-3):113-31.

48. Sekhon-Loodu S, Rupasinghe HPV. Evaluation of Antioxidant, Antidiabetic and Antiobesity Potential of Selected Traditional Medicinal Plants. Frontiers in Nutrition. 2019;6(April):1-11. 
49. Lee YW, Choi SY, Lee EK, Sohn JH, Park J-W, Hong C-S. Cross-allergenicity of pollens from the Compositae family: Artemisia vulgaris, Dendranthema grandiflorum, and Taraxacum officinale. Annals of Allergy, Asthma \& Immunology. 2007;99(6):526-33.

50. Zhu M, Wong PY, Li RC. Effects of Taraxacum mongolicum on the bioavailability and disposition of ciprofloxacin in rats. Journal of Pharmaceutical Sciences. 1999;88(6):632-4. 